\begin{tabular}{|c|c|c|}
\hline $\begin{array}{c}\text { SHORT } \\
\text { COMMUNICATION }\end{array}$ & Open access & http://www.foliahort.ogr.ur.krakow.pl \\
\hline
\end{tabular}

\title{
Winter frost injury of buds on one-year-old grapevine shoots of Vitis vinifera cultivars and interspecific hybrids in Poland
}

\author{
Jerzy Lisek \\ Department of Pomology \\ Research Institute of Horticulture \\ Pomologiczna 18, 96-100 Skierniewice, Poland
}

\begin{abstract}
Following the winter of 2009/2010, an assessment of frost damage was carried out on the vines of 40 wine cultivars and 32 table grape cultivars grown in central Poland (Skierniewice, latitude $51^{\circ} 57^{\prime} \mathrm{N}$, longitude $20^{\circ} 08^{\prime}$ E). The minimum winter temperature of $-28.1^{\circ} \mathrm{C}$ was recorded on 26 January 2010 . Cultivars were assigned to five classes of different frost tolerance, according to information on the percentage of frozen buds: very resistant (below $1.9 \%)$, resistant $(2-24.9 \%)$, medium susceptible $(25-74.9 \%)$, susceptible $(75-95.9 \%)$ and very susceptible (above $96 \%$ ). The numbers of wine and table cultivars in each class were as follows: very resistant -5 (wine) and 3 (table), resistant -2 and 5 , medium susceptible -15 and 10 , susceptible -13 and 9 and very susceptible -5 and 5 . The most tolerant were the 'Alwood', 'Delaware', 'Fredonia' and 'Zilga' interspecific hybrids of the Vitis labruscana group; the 'Aurore', 'Marechal Foch' and 'Leon Millot' hybrids originating from $V$. vinifera, $V$. rupestris, $V$. riparia and $V$. lincecumii and 'Sibera' originating from $V$. vinifera and $V$. amurensis. More than $96 \%$ of buds froze on the vines of some interspecific hybrids ('Arkadia', 'Fanny', 'Kodrianka' and 'Lilla'). 'Ortega', 'Nektar', 'Cserszegi Fueszeres', 'Riesling' and 'Chasselas Dore' from the $V$. vinifera cultivars showed the best tolerance to frost damage (42.5-62\% of frozen buds). The buds of the $V$. vinifera cultivars 'Acolon', 'Dakapo' and 'Favorit' all froze. Plant parts covered with soil and snow were not exposed to significant damage, even in the case of susceptible cultivars.
\end{abstract}

Key words: genotype, tolerance to low temperature, viticulture

\section{INTRODUCTION}

For the past few years there has been mounting interest in the cultivation of grapevine in Poland. Tolerance to frost damage is an essential characteristic that determines the suitability of grapevines for growing in countries where the climate is characterised by frosty winters (Elfving et al. 1985, Fallahi et al. 2001, Kozma 2002, Kriszten 2002, Lisek 2007, 2009). Frost resistance of plants of the genus Vitis is to a large degree determined by a genetic factor, where selection is influenced by the climatic conditions prevailing in the areas of natural diversification of the species (Galet 1988, Alleweldt et al. 1990, Hemstad and Luby 1990, Luby 1991, Reisch and Pratt 1996).

$V$. vinifera is the most commonly grown species in commercial vineyards all over the world. The main reason why it cannot be popularised in Poland is because of its relatively high susceptibility to frost damage, which affects yield. The average frost resistance of buds overwintering on the vines 
of $V$. vinifera is about $-16^{\circ} \mathrm{C}$ (Nikov et al. 1983). Pospišilová (1981) described the frost resistance of cultivars widespread in Central Europe in the conditions of Slovakia - thus similar to those of Poland. Pospišilová and other authors (Alleweldt et al. 1990) stated that most resistant among $V$. vinifera cultivars is 'Riesling,' whose buds endure temperature drops to $-22^{\circ} \mathrm{C}$, or even to $-25^{\circ} \mathrm{C}$. Among wine cultivars characterised by relatively high frost resistance, whose buds usually freeze at temperatures between $-20^{\circ} \mathrm{C}$ and $-22^{\circ} \mathrm{C}$, Pospišilová counts 'Traminer Rot', 'Zweigelt', 'Pinot Gris', 'Pinot Noir' and 'Chardonnay'. 'Sylvaner', 'Mueller Thurgau' and 'Scheurebe' show an average frost resistance, and their buds freeze at temperatures from -18 to $-20^{\circ} \mathrm{C}$. According to Pospišilová, 'Portugieser' and 'Sauvignon' belong to the susceptible cultivars, whose buds endure temperatures up to $-16^{\circ} \mathrm{C}$. Table grapevine cultivars resistant to frost include 'Chasselas Dore' (which can be also used for processing) and 'Pearl of Csaba,' while 'Favorit' is susceptible to frost.

Among the newest cultivars belonging either to $V$. vinifera or to interspecific hybrids, some of which are systematically classified as $V$. vinifera, 'Cabernet Cortis', 'Regent', 'Rondo', 'Roesler', 'Solaris', 'Milia' and 'Muscat Bleu' are resistant to frost. 'Acolon', 'Kerner', 'Sieger' and 'Dornfelder' show average resistance (Kaserer and Blahous 1999, Basler 2002, Pospišilová et al. 2005, Lott et al. 2010). Hybrids originating in Hungary are characterised by very high ('Bianca'), high ('Nero') or moderate ('Palatina') resistance to frost (Hajdu and Gabor 1997, Kozma 2002). In Belarus, Ukraine and southern Russia, overwintering buds of East European hybrids are able to endure up to $-30^{\circ} \mathrm{C}$ ('Ananasnyj Rannyj', 'Zilga'), $-25^{\circ} \mathrm{C}$ ('Aloshenkin', 'Supaga'), from $-21^{\circ} \mathrm{C}$ to $-23^{\circ} \mathrm{C}$ ('Arkadia') and $-22^{\circ} \mathrm{C}$ ('Kodrianka') (Łojko and But-Gusaim 1990, Kostrikin 2002, Abuzov 2009). In the northern states of the USA and south-eastern Canada (Ontario region), interspecific hybrids are grown, created by crossing $V$. vinifera with American species that are more tolerant to winter frosts of $-25^{\circ} \mathrm{C}$ than $V$. vinifera (Elfving et al. 1985, Plocher and Parke 2001). According to the authors cited, in France, in the second half of the $19^{\text {th }}$ century and at the beginning of the $20^{\text {th }}$ century, highly resistant hybrids such as 'Aurore', 'Baco Noir', 'Marechal Foch', and less resistant 'Seyval' were created by crossing $V$. vinifera, $V$. riparia, $V$. rupestris and $V$. lincecumii. Among hybrids obtained by crossing $V$. vinifer $a$ and $V$. labrusca, the most resistant are 'Buffalo', 'Reliance', 'Canadice', 'Einset', 'Price' and 'Festivee' (Elfving et al. 1985, Reisch et al. 1999, Fallahi et al. 2001). The tolerance of grapevines to the effects of low temperatures is influenced by the plant age, health status, yielding of bushes and weather conditions during the vegetative period (Hajdu and Gabor 1997, Wample et al. 1997). The scale of frost damage depends not only on low temperatures but also on temperature fluctuations and the wind (Plocher and Parke 2001). The evaluation of frost resistance, carried out in field conditions, like the study described, takes into consideration the influence of all factors on the wintering of bushes. The aim of the study was to assess the frost tolerance of buds on oneyear-old woody shoots of wine and table cultivars that may be used in the process of establishing commercial vineyards as well as in home gardens and agritourism farms.

\section{MATERIAL AND METHODS}

The assessment of frost damage of vines was carried out in the field collection of grapevines located in the Pomological Orchard of the Institute of Horticulture in Skierniewice, on a podsolic soil graded Class IV, slightly acidic $(\mathrm{pH} 6.3)$ and containing $1.3 \%$ of organic matter. Each of the genotypes was represented by three vines, planted at a spacing of $2.5 \times 1 \mathrm{~m}$ and trained according to the 'low-head' method. One to three trunks, $20 \mathrm{~cm}$ in height, were formed on the vines. After winter pruning, 6-8 evenly spaced canes, each with 2-3 buds, were left on the vine (spur pruning). In July, the shoots were pruned above the $10^{\text {th }}-12^{\text {th }}$ leaf past the last cluster of grapes. The lateral branches of the young shoots were cut back above the first or second leaf counting from the base.

The frost damage of the vines was assessed following the weather conditions described in Table 1. The sum of active temperatures (SAT) in 2009 amounted to $2530^{\circ} \mathrm{C}$, which did not differ from the average from the period 1981-2010. In November, the temperature did not decrease below $-10^{\circ} \mathrm{C}$, which allowed the plants a gradual adaptation to winter conditions. Extremely low temperatures, below $-20^{\circ} \mathrm{C}$, occurred in the last five days of January.

Forty valuable cultivars of grapevine for wine production and 32 cultivars of table grapevine were selected for the study out of the 234 cultivars and hybrids represented in the collection. Information on the cultivars, such as origin, berry skin colour and fruit type, is given in Tables 2 and 3. Frost damage 
Table 1. Climatic conditions in Skierniewice in the period July 2009 - April 2010

\begin{tabular}{lccccc}
\hline \multirow{2}{*}{ Year } & Month & \multicolumn{3}{c}{ Air temperature $\left({ }^{\circ} \mathrm{C}\right)$} & Precipitation $(\mathrm{mm})$ \\
\cline { 3 - 5 } & July & $\begin{array}{c}\text { Minimum } \\
\text { (date })\end{array}$ & $\begin{array}{c}\text { Maximum } \\
(\text { date })\end{array}$ & Average monthly & 77.2 \\
\hline 2009 & $7.7(12.07)$ & $31.4(23.07)$ & 18.9 & 72.8 \\
& August & $6.7(20.08)$ & $29.7(17.08)$ & 17.7 & 29.0 \\
& September & $1.6(19.09)$ & $26.5(03.09)$ & 14.2 & 83.4 \\
& October & $-6.7(31.10)$ & $23.5(08.10)$ & 6.3 & 59.4 \\
& November & $-4.9(01.11)$ & $11.9(20.11)$ & -1.3 & 41.6 \\
& December & $-21.4(19.12)$ & $10.6(01.12)$ & -9.0 & 0.0 \\
& January & $-28.1(26.01)$ & $1.6(18.01)$ & -2.2 & 22.2 \\
& February & $-14.8(08.02)$ & $7.2(25.02)$ & 3.3 & 40.2 \\
\hline
\end{tabular}

to the buds that were not covered with soil (mounds of $40 \mathrm{~cm}$ ) or snow (layer not thicker than $10 \mathrm{~cm}$ above the mounds) during the frosts was assessed at the time of cutting back the woody shoots in the second half of March and at the beginning of April. From each of the plots occupied by the cultivars, four samples of cane were taken, each with 50 buds. Three samples (replications) came from different vines, while the fourth one consisted of shoots taken in equal parts from the three plants being assessed. One-year-old completely woody shoots, free from structural damage and disease symptoms, were taken from vines that were at least four years old, from the parts of bushes that were not covered with soil or snow. The buds under assessment were cut across with a knife, and the colour of the incipient shoots was determined. An over-wintering bud was considered to be dead if both the main bud and the replacement buds underneath were dark brown. The percentages of buds damaged by frost in relation to the total number of buds were analysed statistically using the analysis of variance, which was applied to the values after Bliss' transformation. The significance of difference between the means was assessed using the Duncan test at the 5\% level. Cultivars were assigned to five classes of different frost tolerance according to information on the percentage of frozen buds: very resistant (below $1.9 \%)$, resistant $(2-24.9 \%)$, medium susceptible $(25-74.9 \%)$, susceptible $(75-95.9 \%)$ and very susceptible (above 96\%).In the last ten days of April, an assessment of frost damage was also carried out on the buds remaining on the vines, which at the time of the frosts were covered with soil or snow. During the vegetative period, the effect of low winter temperatures on the growth and yielding of the vines was also assessed.

\section{RESULTS AND DISCUSSION}

Frost tolerance, expressed as the percentage of surviving buds exposed to low temperatures during winter, highly varied among the 72 grapevine cultivars (Tabs 1 and 2). Out of 40 wine grapevine cultivars, 5 were acknowledged as very resistant, 2 resistant, 15 - medium susceptible, 13 - susceptible and 5 - very susceptible. From among 32 table grapevine cultivars, 3 were proved to be very resistant, 5 - resistant, 10 - medium susceptible, 9 - susceptible, 5 - very susceptible.

Even in the case of cultivars most susceptible to frost damage, the buds that were covered during winter with at least $5 \mathrm{~cm}$ of soil survived well (no damage or one damaged bud per bush) and continued to develop properly in the growing season.

Most commercial vineyards are planted in regions where the temperature dropping to $-25^{\circ} \mathrm{C}$ would be considered an abnormal weather condition. Severe winters, with temperature drops to $-28^{\circ} \mathrm{C}$, like in the $2009 / 2010$ season, prove that the frost resistance of both the vines and their overwintering buds is an essential criterion in assessing the usefulness of cultivars that may be grown in Poland. The research described allows for a comparison of earlier and newer results concerning the frost resistance of grapevine cultivars obtained in Skierniewice and other places in Poland as well as abroad. It also enriches our knowledge of some promising cultivars whose frost resistance in Polish conditions had not yet been evaluated.

The research confirmed the fact that due to severe winters and the high costs of protecting the vineyards against cold, interspecific hybrids are most suitable to Polish conditions. Among the wine cultivars, in accordance with previous reports, the older hybrids of 
Table 2. Frost damage to wine grapevines following the winter of 2009/2010

\begin{tabular}{|c|c|c|c|c|c|}
\hline Cultivar & $\begin{array}{c}\text { Colour of berry } \\
\text { skin* }^{*}\end{array}$ & Origin $^{* *}$ & $\begin{array}{c}\text { Country of } \\
\text { breeding }\end{array}$ & $\begin{array}{c}\text { Frozen buds } \\
(\%)^{* * *}\end{array}$ & $\begin{array}{l}\text { Class of frost } \\
\text { tolerance } e^{* * * *}\end{array}$ \\
\hline Acolon & $\mathrm{N}$ & Vin & Germany & $100.0 \mathrm{t}$ & VS \\
\hline Aurore (amatour) & $\mathrm{B}$ & $\mathrm{IH}$ & France & $0.1 \mathrm{ab}$ & VR \\
\hline Bianca & $\mathrm{B}$ & IH & Hungary & $61.5 \mathrm{hi}$ & MS \\
\hline Cabernet Cortis & $\mathrm{N}$ & $\mathrm{IH}($ Amur $)$ & Germany & $65.0 \mathrm{ij}$ & MS \\
\hline Cabernet Dorsa & $\mathrm{N}$ & Vin & Germany & $81.1 \mathrm{kl}$ & $\mathrm{S}$ \\
\hline Chardonnay (Gm 53) & $\mathrm{B}$ & $\operatorname{Vin}$ & France (Germany) & $89.0 \mathrm{mn}$ & $\mathrm{S}$ \\
\hline Cserszegi Fueszeres & $\mathrm{B}-\mathrm{R}$ & $\operatorname{Vin}$ & Hungary & $54.5 \mathrm{~h}$ & MS \\
\hline Dakapo & $\mathrm{N}$ & Vin & Germany & $100.0 \mathrm{t}$ & VS \\
\hline Delaware (amatour) & $\mathrm{R}$ & $\mathrm{IH}(L a b)$ & USA & $0.0 \mathrm{a}$ & VR \\
\hline Dornfelder & $\mathrm{N}$ & Vin & Germany & $93.2 \mathrm{opq}$ & $\mathrm{S}$ \\
\hline Johanniter & $\mathrm{B}$ & $\mathrm{IH}$ & Germany & $61.0 \mathrm{hi}$ & MS \\
\hline Kerner & $\mathrm{B}$ & Vin & Germany & $94.5 \mathrm{pq}$ & $\mathrm{S}$ \\
\hline Leon Millot & $\mathrm{N}$ & $\mathrm{IH}$ & France & $0.7 \mathrm{bc}$ & VR \\
\hline Marechal Foch & $\mathrm{N}$ & $\mathrm{IH}$ & France & $0.0 \mathrm{a}$ & VR \\
\hline Merzling & B & $\mathrm{IH}$ & Germany & $45.5 \mathrm{~g}$ & MS \\
\hline Milia & $\mathrm{B}-\mathrm{R}$ & $\operatorname{Vin}$ & Slovakia & $70.6 \mathrm{j}$ & MS \\
\hline Mueller Thurgau & $\mathrm{B}$ & Vin & Germany & $99.9 \mathrm{t}$ & VS \\
\hline Nektar & B & Vin & Hungary & $47.5 \mathrm{~g}$ & MS \\
\hline Orion & $\mathrm{B}$ & $\mathrm{IH}$ & Germany & $85.5 \mathrm{~lm}$ & $\mathrm{~S}$ \\
\hline Ortega & $\mathrm{B}$ & Vin & Germany & $42.5 \mathrm{~g}$ & MS \\
\hline Phoenix & B & $\mathrm{IH}$ & Germany & $94.6 \mathrm{pq}$ & $\mathrm{S}$ \\
\hline Pinot Blanc & $\mathrm{B}$ & $\operatorname{Vin}$ & France & $95.5 \mathrm{qr}$ & $\mathrm{S}$ \\
\hline Pinot Gris & $\mathrm{R}$ & $\operatorname{Vin}$ & France & $81.1 \mathrm{kl}$ & $\mathrm{S}$ \\
\hline Pinot Noir & $\mathrm{N}$ & $\operatorname{Vin}$ & France & $85.0 \mathrm{~lm}$ & $\mathrm{~S}$ \\
\hline Pinot Noir Precoce & $\mathrm{N}$ & Vin & France & 90.5 no & $\mathrm{S}$ \\
\hline Portugieser & $\mathrm{N}$ & $\operatorname{Vin}$ & Austria & $98.5 \mathrm{~s}$ & VS \\
\hline Riesling & $\mathrm{B}$ & $\operatorname{Vin}$ & Germany & $60.5 \mathrm{hi}$ & MS \\
\hline Regent & $\mathrm{N}$ & $\mathrm{IH}$ & Germany & $60.3 \mathrm{i}$ & MS \\
\hline Roesler & $\mathrm{N}$ & IH & Austria & $47.0 \mathrm{~g}$ & MS \\
\hline Rondo & $\mathrm{N}$ & $\mathrm{IH}($ Amur $)$ & Germany & $32.0 \mathrm{f}$ & MS \\
\hline Saphira & B & $\mathrm{IH}$ & Germany & $24.0 \mathrm{e}$ & $\mathrm{R}$ \\
\hline Sauvignon & $\mathrm{B}$ & Vin & France & $97.6 \mathrm{rs}$ & VS \\
\hline Scheurebe & $\mathrm{B}$ & Vin & Germany & 91.8 nop & $\mathrm{S}$ \\
\hline Seyval & $\mathrm{B}$ & $\mathrm{IH}$ & France & $11.8 \mathrm{~d}$ & $\mathrm{R}$ \\
\hline Sibera & B & IH (Amur) & Germany & $1.1 \mathrm{c}$ & VR \\
\hline Sieger & $\mathrm{R}$ & Vin & Germany & $80.5 \mathrm{kl}$ & $\mathrm{S}$ \\
\hline Solaris & $\mathrm{B}$ & IH (Amur) & Germany & $27.0 \mathrm{ef}$ & MS \\
\hline Sylvaner & B & Vin & Austria & $99.9 \mathrm{t}$ & VS \\
\hline Traminer Rot & $\mathrm{R}$ & Vin & Italy & $66.1 \mathrm{ij}$ & MS \\
\hline Zweigelt & $\mathrm{N}$ & Vin & Austria & $77.6 \mathrm{k}$ & $\mathrm{S}$ \\
\hline
\end{tabular}

Amatour - cultivar for noncommercial (home) wine

*Colour of berry skin: B (blanc) - green-yellow, R - rose, N (noir) - blue-black;

**Origin: Vin $-V$. vinifera; IH - interspecific hybrid from crossing $V$. vinifera and at least two species from among $V$. riparia, $V$. rupestris, $V$. lincecumii; Amur - hybrid with V. amurensis; Lab - hybrid with V. labrusca;

$* * *$ Means followed by the same letter do not differ significantly at $\mathrm{p}=0.05$

$* * * *$ Class of frost tolerance: very resistant (below $1.9 \%$ of frozen buds), resistant $(2-24.9 \%)$, medium susceptible $(25-74.9 \%)$, susceptible (75 - 95.9\%) and very susceptible (above 96\%)

$V$. vinifera, $V$. riparia, $V$. rupestris and $V$. lincecumii ('Aurore', 'Leon Millot', 'Marechal Foch' and 'Seyval') and newer hybrids 'Saphira' and 'Sibera' were highly resistant. The resistance of hybrids crossed with $V$. labrusca ('Delaware', 'Alwood, 'Ananasnyj Rannyj', 'Festivee', 'Einset', 'Price', 'Supaga' and 'Zilga') was confirmed, similarly to conditions in the USA, Canada, Belarus and Ukraine (Elfving et al. 1985, Łojko and But-Gusaim 1990, Reisch et al. 1999, Kostrikin 2002, Abuzov 2009).
The tolerance of new hybrids highly varied. Within the group of wine cultivars, the 'Phoenix' and 'Orion' hybrids proved to be far more prone to damage than 'Riesling' (belonging to $V$. vinifera), considered as the standard of high tolerance within its species (Pospišilová 1981, Alleweldt et al. 1990). Hybrids of table grapevines 'Arkadia', 'Eszter', 'Kodrianka', 'Fanny', 'Flora', 'Lidi', 'Lilla' and 'Palatina' were more prone to damage than the standard $V$. vinifera cultivar 'Chasselas 
Table 3. Frost damage to table grapevines following the winter of 2009/2010

\begin{tabular}{|c|c|c|c|c|c|}
\hline Cultivar & $\begin{array}{l}\text { Colour of } \\
\text { berry skin* }\end{array}$ & Origin $^{* *}$ & $\begin{array}{c}\text { Country of } \\
\text { breeding }\end{array}$ & $\begin{array}{c}\text { Frozen } \\
\text { buds }(\%)^{* * *}\end{array}$ & $\begin{array}{l}\text { Class of frost } \\
\text { tolerance } \text { e }^{* * * *}\end{array}$ \\
\hline Alden & $\mathrm{N}$ & $\mathrm{IH}(L a b)$ & USA & 63.01 & MS \\
\hline Aloshenkin & $\mathrm{B}$ & Seedling of Vin & Russia & $75.6 \mathrm{~m}$ & $\mathrm{~S}$ \\
\hline Alwood $(\mathrm{N})$ & $\mathrm{N}$ & IH $(L a b)$ & USA & $0.0 \mathrm{a}$ & VR \\
\hline Ananasnyj Rannyj & $\mathrm{B}$ & $\mathrm{IH}(L a b)$ & Ukraine & $12.9 \mathrm{~cd}$ & $\mathrm{R}$ \\
\hline Arkadia & $\mathrm{B}$ & IH & Ukraine & $99.5 \mathrm{r}$ & VS \\
\hline Buffalo & $\mathrm{N}$ & $\mathrm{IH}(L a b)$ & USA & $26.0 \mathrm{e}$ & MS \\
\hline Canadice & $\mathrm{R}$ & $\mathrm{IH}(L a b)$ & USA & $51.0 \mathrm{jk}$ & MS \\
\hline Century & $\mathrm{R}-\mathrm{N}$ & IH & USA & $83.1 \mathrm{n}$ & $\mathrm{S}$ \\
\hline Chasselas Dore & B & Vin & unknown & 62.01 & MS \\
\hline Einset & $\mathrm{R}$ & $\mathrm{IH}(L a b)$ & USA & $16.9 \mathrm{~d}$ & $\mathrm{R}$ \\
\hline Eszter & $\mathrm{N}$ & IH & Hungary & $95.5 \mathrm{q}$ & $\mathrm{S}$ \\
\hline Fanny & $\mathrm{B}$ & $\mathrm{IH}$ & Hungary & $97.1 \mathrm{q}$ & VS \\
\hline Favorit & $\mathrm{B}$ & Vin & Hungary & $100.0 \mathrm{~s}$ & VS \\
\hline Festivee & $\mathrm{N}$ & $\mathrm{IH}(L a b)$ & Canada & $2.9 \mathrm{~b}$ & $\mathrm{R}$ \\
\hline Flora & $\mathrm{R}$ & $\mathrm{IH}$ & Hungary & 90.7 op & $\mathrm{S}$ \\
\hline Fredonia & $\mathrm{N}$ & $\mathrm{IH}(L a b)$ & USA & $0.0 \mathrm{a}$ & VR \\
\hline Garant & $\mathrm{B}$ & IH & Germany & $34.0 \mathrm{fg}$ & MS \\
\hline Iza & $\mathrm{B}$ & $\mathrm{IH}(L a b)$ & unknown (likely Poland) & $54.0 \mathrm{k}$ & MS \\
\hline Kodrianka & $\mathrm{N}$ & IH & Moldova & 99.9 rs & VS \\
\hline Lidi & $\mathrm{R}$ & $\mathrm{IH}$ & Hungary & 90.0 op & $\mathrm{S}$ \\
\hline Lilla & $\mathrm{B}$ & $\mathrm{IH}$ & Hungary & $99.5 \mathrm{r}$ & VS \\
\hline Muscat Bleu & $\mathrm{N}$ & $\mathrm{IH}$ & Switzerland & $29.0 \mathrm{ef}$ & MS \\
\hline Narancsizü & $\mathrm{B}$ & Vin & Hungary & $83.1 \mathrm{n}$ & $\mathrm{S}$ \\
\hline Nero & $\mathrm{N}$ & IH & Hungary & $46.0 \mathrm{ij}$ & MS \\
\hline New York Muskat & $\mathrm{R}-\mathrm{N}$ & $\mathrm{IH}(L a b)$ & USA & $38.0 \mathrm{gh}$ & MS \\
\hline Palatina & B & IH & Hungary & $87.6 \mathrm{o}$ & $\mathrm{S}$ \\
\hline Pearl of Csaba & $\mathrm{B}$ & Vin & Hungary & $83.1 \mathrm{n}$ & $\mathrm{S}$ \\
\hline Price & $\mathrm{N}$ & $\mathrm{IH}(L a b)$ & USA & $11.4 \mathrm{c}$ & $\mathrm{R}$ \\
\hline Supaga & $\mathrm{B}$ & $\mathrm{IH}(L a b)$ & Latvia & $14.0 \mathrm{~cd}$ & $\mathrm{R}$ \\
\hline Reliance & $\mathrm{R}$ & $\mathrm{IH}(L a b)$ & USA & $41.0 \mathrm{hi}$ & MS \\
\hline Topas & B & Vin & Slovakia & $91.6 \mathrm{p}$ & $\mathrm{S}$ \\
\hline Zilga & $\mathrm{N}$ & $\mathrm{IH}(L a b)$ & Latvia & $0.0 \mathrm{a}$ & VR \\
\hline
\end{tabular}

$*, * *, * * *, * * * *$ Explanations: see Table 2

Dore'. Relatively tolerant to frost damage wine hybrids ('Bianca', 'Cabernet Cortis', 'Johanniter', 'Merzling', 'Regent', 'Roesler', 'Rondo' and 'Solaris') and table grapevine hybrids characterised by well-toned, attractive fruit ('Garant', 'Muscat Bleu' and 'Nero') may prove sufficiently resistant to be grown in western parts of Poland, where winters tend to be milder than in central and eastern parts.

Among wine cultivars, 'Nektar' proved to be more tolerant than 'Riesling', which confirmed previous reports (Lisek 2009), and 'Ortega'. 'Cserszegi Fueszeres' suffered damage similar to 'Riesling'. The assessment carried out after the winter of 2009/2010 confirmed the high tolerance of 'Milia' and the standard cultivar 'Traminer Rot' in Skierniewice and Slovakia alike (Pospišilová et al. 2005, Lisek 2009). Among table cultivars of $V$. vinifera, 'Pearl of Csaba' and 'Chasselas Dore' showed higher frost tolerance than 'Topas' or 'Favorit' (Pospišilová 1981, Pospišilová et al. 2005). Frost resistance depends not only on the main, genetic, factor, but also on the age and health of plants, good or poor harvest and climatic course of the season preceding the overwintering (Hajdu and Gabor 1997, Wample et al. 1997). The great number of factors may cause results obtained in various years and locations to differ. For instance, after the winter of 2008/2009, when the minimum temperature dropped to $-23^{\circ} \mathrm{C}$, 'Solaris' buds suffered damage of $50.5 \%$ and 'Rondo' buds of $56.5 \%$ (Lisek 2009). The damage was more severe than after the much colder winter of 2009/2010. Data concerning frost resistance should be verified within the country, as it may differ from results obtained abroad. The 'Reliance' cultivar may serve a good example since its buds on one-year-old shoots, in this research, proved more susceptible to frost damage than in the north-eastern USA, where they are able to endure temperatures dropping to $-34^{\circ} \mathrm{C}$ (Fallahi et al. 2001). The juxtaposition of results with data gathered by other researchers demonstrates that further systematic study is needed, 
especially in account of the mounting interest in grapevine growing in Poland and the popularisation of new cultivars. Results concerning the hardiness of buds cannot be explicitly rendered into a guideline on the technology of cultivation. The research on the biology and yielding of damaged bushes carried out in Skierniewice indicates the need for covering the bushes of those cultivars, whose damage exceeded $30-40 \%$ in the described studies, for winter.

\section{CONCLUSIONS}

1. Among $V$. vinifera genotypes, the highest frost tolerance of overwintering buds was shown by vines of the 'Ortega', 'Nektar, 'Cserszegi Fueszeres', 'Riesling' and 'Chasselas Dore' cultivars.

2. Several hybrids created by crossing $V$. vinifera with $V$. labrusca ('Alwood', 'Festivee', 'Price', 'Supaga' and 'Zilga'); V. riparia, V. rupestris, and $V$. lincecumii ('Aurore', 'Baco Noir', Marechal Foch', 'Leon Millot', 'Seyval' and 'Saphira') and $V$. amurensis ('Sibera') belonged to the group of vines most resistant to cold. The buds of 'Orion', 'Phoenix', 'Arkadia' and 'Kodrianka' hybrids were more susceptible to frost damage than the most tolerant among the $V$. vinifera cultivars.

3. The frost tolerance of 'Bianca', 'Cabernet Cortis', Johanniter' and 'Regent', which are the most perspective wine cultivars in Poland, was good comparable to most $V$. vinifera cultivars but not sufficient in the conditions of cold winters which occur in central Poland every couple of years.

\section{REFERENCES}

Abuzov M., 2009. Atlas sieviernovo vinograda. KFH Pitomnik. Smoleńsk.

Alleweldt G., Spiegel-Roy P., Reisch B.I., 1990. Grapes (Vitis). Acta Hort. 290: 291-337.

BASLER P., 2002. Ungespritzte einheimische Tafeltrauben. Schweiz. Z. Obst-Weinbau 138(7): 169-170.

Elfving D.C., Dale A., Fisher K.H., Tehrani G., 1985. Fruit cultivars. Publication 430. Ministry of Agriculture and Food, Ontario.

Fallahi E., Fallahi B., Chun I.J., 2001. Adaptation, maturity and fruit quality of table grapes in the intermountain West region of USA. Small Fruits Review 1(4): 29-42.

Galet P., 1988. Cépages et vignobles de France, Tome I. Les vignes Américaines. $2^{\text {nd }}$ ed. Déhan, Montpellier.

Hajdu E., Gabor G., 1997. Winter tolerance of grape varieties in the winter 1995/1996. HortSci. 29(1-2): 43-47.
Hemstad P.R., Luby J.J., 1990. Evaluation and utilization of Vitis riparia as a source of genes for extreme cold hardiness. Proc. $5^{\text {th }}$ Int. Symp. On Grape Breeding, 12-16 September 1989. St. Martin/Pfalz, Germany. Vitis special issue: 29.

Kaserer H., Blahous D., 1999. Pilztolerante RotweinNeuzuchtungen aus Klosterneuburg Roesler, Rathay and Seifert. Der Deutsche Weinbau 13: 28-30.

Kostrikin I.A., 2002. Ustojcziwyje sorta vinograda genofonda SNG. Rostov-Odessa-Zaporoże.

Kozma P., JR., 2002. Resistant grape varieties originating from Franco-American hybrids in Hungary. Int. J. Hort. Sci. 8(1): 47-50.

KRISZTEN G.Y., 2002. Vitis interspecific hybrids in grape production. Int. J. Hort. Sci. 8(1): 57-59.

LISEK J., 2007. Frost damage of grapevines in Poland following the winter of 2005/2006. Folia Hort. 19(2): 69-78.

LiseK J., 2009. Frost damage of buds on one-yearold shoots of wine and table grapevine cultivars in central Poland following the winter of 2008/2009. J. Fruit Ornam. Plant Res. 17(2): 149-161.

Lott H., Pfaff F., Prior B., 2010. Taschenbuch der Rebsorten. 14 Auflage. Fachverlag Dr. Fraund $\mathrm{GmbH}$, Mainz.

LuBY J.J., 1991. Breeding cold-hardy fruit crops in Minnesota. HortSci. 26: 505-512.

Łojko R.E., But-Gusaim A.W., 1990. Sorta vinograda w Biełorusii. Biełorusskij Nauczno-Issledovatelskij Institut. Mińsk.

Nikov M., Jonev S., CzoŁakov T., Malenin I., Todorov I., Monov I., 1983. Spravocznik po łozarstvo. Ch. Danov. Plovdiv.

Plocher T.A., Parke R.J., 2001. Northern Winework. Eau Claire Printing Co., Minnesota.

Pospišilová D., 1981. Ampelografia CSSR. Priroda. Bratislava.

Pospišilová D., Sekera D., Ruman T., 2005. Ampelografia Slovenska. 1 vyd. Modra VSSVVM.

Reisch B.I., Pratt C., 1996. Grapes. In: J. Janick and J.N. Moore (eds). Fruit Breeding. Vol. II: Vine and Small Fruits Crops, John Wiley \& Sons, New York, USA: 297-366.

Wample R.L., Wolf T.K., Henick-Kling T., Harkness E.M., 1997. Practical considerations that impact vine cold hardiness. Proc. $4^{\text {th }}$ Inter. Symp. Cool Climate Viticulture and Enology, Rochester, New York, 16-20 July 1996, II: 23-38.

\section{USZKODZENIA MROZOWE PAॄKÓW ZIMUJACCYCH NA JEDNOROCZNYCH PĘDACH ODMIAN WINOROŚLI WŁAŚCIWEJ I MIĘDZYGATUNKOWYCH MIESZAŃCÓW WINOROŚLI W WARUNKACH POLSKI}

Streszczenie: Po zimie 2009/2010 oceniano uszkodzenia mrozowe na krzewach czterdziestu winiarskich i trzydziestu dwóch deserowych odmian 
winorośli uprawianych $\mathrm{w}$ warunkach centralnej Polski. Minimalną temperaturę zimową, wynosząca $-28,1^{\circ} \mathrm{C}$, zanotowano 26 stycznia 2010 . Odmiany podzielono na 5 klas o różnej odporności na mróz: bardzo odporne (poniżej 1,9\% przemarzniętych pąków), odporne $(2-24,9 \%)$, średnio wrażliwe (25 - 74,9\%), wrażliwe $(75-95,9 \%)$ i bardzo wrażliwe (ponad 96\%). Liczba odmian przerobowych i deserowych w poszczególnych klasach tolerancji była następująca: bardzo odporne odpowiednio 5 (na wino) i 3 (deserowe), odporne - 2 i 5, średnio wrażliwe - 15 i 10, wrażliwe - 13 i 9 , bardzo wrażliwe - 5 i 5. Do klasy o najlepszej tolerancji na ekstremalnie niską temperaturę należały mieszańce międzygatunkowe, zaliczane do grupy $V$. labruscana, 'Alwood', 'Delaware', 'Fredonia' i 'Zilga'; mieszańce 'Aurora', 'Marechal
Foch', 'Leon Millot' pochodzące od $V$. vinifera, $V$. rupestris, V. riparia, V. lincecumii i 'Sibera', wyhodowany z udziałem $V$. amurensis. Na krzewach niektórych mieszańców międzygatunkowych ('Arkadia', 'Fanny', 'Kodrianka', 'Lilla') przemarzło więcej niż 96\% pąków. Spośród odmian winorośli właściwej ( $V$. vinifera), najmniejszą podatność na uszkodzenia mrozowe wykazały 'Ortega', 'Nektar', 'Cserszegi Fueszeres', 'Riesling' i 'Chrupka Złota' ('Chasselas Dore') (42,5-62\% przemarzniętych pąków). Na krzewach odmian winorośli właściwej 'Acolon', 'Dakapo' i 'Favorit', przemarzły wszystkie pąki. Części roślin okryte glebą i śniegiem nie były narażone na istotne uszkodzenia, nawet u wrażliwych odmian.

Received December 8, 2011; accepted April 16, 2012 